\title{
「高田保馬のイルネスとリカバリー」 書評論文リプライ
}

\section{金子 勇*}

一般的に「書評」は気の重い仕事である。ましてや異なる 4 冊の対象書（以下 $\lceil 4$ 冊本」と表記）を限られた紙数にまとめることは大変であり，早川の「書評論 文」に心から感謝する。ただし，書評とは対象書の特徽を功罪あわせて「自分の 思索と言葉で論評する」ことが最大の任務であるとすれば，早川の「書評論文」 では「4冊本」の特徴として編者が力点を置いたところが読み取れていないばかり か, 自分の思索というよりは清水幾太郎の論点を借りたままのコメントに終わった印 象が強い. 早川が「形式社会学者を自認」するのは勝手だが, 高田保馬（1883-1972） は「形式社会学者」に押し込めない知的巨人であるから，「形式社会学」から見て 「失望に変わっていった」のは仕方がない.

ただその失望の延長線上に書かれた「つまらない数冊であり, 読导は苦痛で あるが，読まないよりも読んだほうがいい」という程度の「書評論文」では，「4 冊本」の企画編集者としては納得がいかない。長年にわたり企画を温めて，1年間 で一気に編集し刊行した意図が読者に全く伝わらないからである。すでに『高田 保馬リカバリー』の「書評」では, 高田門下の内海洋一大阪大学名誉教授が, 「高 田先生の論文を丹念に研究し, 克明に解説し, 適切に論評」(『経済社会学会年報』 XXVI, 2004：211-22） と指摘されてもいるので, 特に30歳代の若い研究者の方々に, 「4冊本」のどこをどのように思索の素材にしていただきたいかを要約しつつ，早 川へのリプライに代えたい. なおこれまでの高田保馬論では, 没後 9 年目の『高 田保馬博士の生涯と学説』（創文社，1981）が一番の広がりをもち, 参考になると ころも多い.

その『高田保馬博士の生涯と学説』の 2 年後が生誕 100 年であったが，日本社会 学会でも出版界でもとくに何も行われなかった. その頃の社会学者の大半はすで に高田作品を読まず，触れず，語らずであった．たまに語るときには，60年前の 一部の言説のみを針小棒大に取り上げて批判するというパターンが出来上がって いた。それはその後に「高田保馬」をタイトルにした 2 冊の社会学書, すなわち 河村望『高田保馬の社会学』(いなほ書房, 1992) と北島滋『高田保馬』(東信堂,

\footnotetext{
* 北海道大学大学院教授 isamu@let.hokudai.ac.jp
} 
2002）でもみごとに継承されている，両書ともにはじめから高田保馬を酷評する 意図をあらわにした本であり，高田社会学の継承と応用をまったく放棄している と私には思われた。

そもそも日本社会学会で，複数の研究者が一同に会したかたちで「高田保馬」 を取り上げたのは逝去の年だけである．1つは『社会学評論』(90号 1972年9月) であり，もう1つは1972年 10 月の法政大学を会場とする第 47 回大会であり， シ ンポジウム「日本社会学と高田社会学」が午前 9 時半から午後 5 時まで開催された. 高田理論社会学に忠実な向井利昌, 全面批判者の宇津栄祐, 意義と有効性を強調 する富永健一の諸氏らの発表，吉田民人，稲上毅，小室直樹氏らのコメントを， 大学院修士課程 1 年の私は末席で择聴した。

このような日本社会学会に扔ける高田保馬評価の仕方や継承方法に疑問を抱き つつも, 私の直接のテーマは都市社会学, コミュニティ論, 高齢社会研究, 少子 社会研究であったため, 高田保馬論を展開する機会は生誕 110 年を迎えても訪れ なかった.

並行して高田逝去後 30 年間の日本社会学会は, 彼の膨大で独創的な業績に対し て冷ややかであり続けた。それ机清水幾太郎が1972年の高田逝去直後にのべ，清 水の没後著作集に再録された「著書と一緒に著者も忘れられてしまっている」 (『清水幾太郎著作集 18』講談社，1993：305)，「日本の社会学掞よび経济学の発 展に決定的な役割を果した人物と業績に対して, 戦後の日本は, 告別式の日の京 都の大気よりも冷たい」（同上：306）ままである。早川が「4冊本」の書評に借用 した清水論文の結論が実はこれである。「形式社会学者を自認する」早川にとって， 高田社会学は高く䈐えていて，「あまり登られることのない高峰」（富永健一「解 説 高田保馬の社会学理論」高田保馬『社会学概論』岩波書店，1971：370）であ り続けるのであろう。

結局，高田への総合評価は，「偉大な才能の持主が，正当な評価をかち得ずして 時流と戦いつづけていた姿を思い出すのは痛ましい」(森嶋通夫「誠実の証として の学問」『高田保馬博士の生涯と学説』創文社，1981：190）ところにあり，そし てその「正当な評価」はいまだなされていない.

しかし，21 世紀日本で最大の課題になる少子化や長寿化研究の理論社会学の素 材に，人口史観の応用が有効なことは自明である。高弟・森嶋通夫のみがその晚 年に人口史観を応用し，『なぜ日本は没落するか」(岩波書店，1999）を残してく れたことはせめてもの救いであった。また『勢力論』は国際化や地方分権化の両 方にも，そして官僚制研究にも多大のヒントを提供する。『社会学概論』は今日で も社会学書の標準化の素材を提供する内容を十分に兼亦備えている.

生誕 110 年を過ぎた 1994 年ころから，私の年来のテーマである年少人口の減少， 高齢者の激増, 総人口の漸減という「三位一体」の未曾有の人口変動に取り組む ほど，時間を割いてでも人口史観を軸としての高田保馬論を行いたいと考えるよ うになった。そのきっかけが生誕 120 年直前の 2002 年 12 月の再度の佐賀県三日月 
町生家訪問と，生誕 110 年を契機に郷里で発足した「高田保馬博士顕彰会」での ヒアリングであった.

その直後に『西日本新聞』(2003年 2 月 15 日) で『高田保馬リカバリー』の企 画と 6 冊の復刻版の決意表明をし, 構想をまとめ, 出版社に交渉し, 生誕 120 周年 記念事業として 2003 年 12 月末までに全冊揃えたいと希望した。しかし，諸事情に より, 今回の 3 冊復刻のみを優先して『高田保馬リカバリー』と合わせた「4冊本」 が, 著作権継承者のご遺族, 出版社, 東京大学名誉教授富永健一氏はじめ解説論 文執筆者や「展望」論文執筆者の全面的なご支援をいただき，ほぼ予定通り刊行 されたあとの 3 冊のコピーは出版社に保管されたままである.

「4冊本」を刊行したあとで，多くの方々からいい仕事だというおたよりを頂戴 したが，同時に都市調査を主体とする実証研究派のあなたがなぜ「高田保馬論」 を仕掛けたのかという疑問文付きが目立った。 その個人的な理由はこれら「4冊本」 の序文や私の解説で触れているし, 一部は『都市の少子社会』（東京大学出版会, 2003）でも書いている。ここではそのような個人的理由とは別に，ほぼ30年間の ささやかな自らの研究史で感じていた事情を明らかにして㧍こう.

1つは日常的なゼミや講義で (A)「学説の継承性」不足を痛感していたからで ある. 高田保馬だけではなく, ウェーバー, デュルケム, パーソンズら大家の理 論を翻訳でも読まない若い世代が増えてきた反面，依然として流行学説の簡単な 紹介としかいえない内容の雑誌論文の多さが気になっていた。『社会学的創造力』 （ミネルヴァ書房，2000）のエピソード（41頁）に記したように，学生時代から 私は「誰を研究するか」という問いでは不十分であり，「何をどのように明らかに するか」を課題にしようと心がけ，輸入紹介業を避けてきた。ライフワークの 「少子化する高齢社会研究」に有効と思われる高田保馬の「人口史観」の応用を手 がかりに，「4冊本」で（a）「学説の評価」の仕方とそれから派生する（b）「学説 の応用」を試みようとしたのである。

これはほほ自動的に（B）社会学の現状分析志向に直結する。私は対極にある ミクロ社会学・マイノリティ研究を眺めながら, マクロ社会学の観点からのマジ ヨリティ研究を優先してきた，しかし，最近のマイノリティ研究に感じられるマ ジョリティへの視野のそしさや，時代診断というセンスに欠けるミクロ社会学で は, 先進社会としての日本またアジアの一部としての日本が抱える構造的課題の 解明はできないと判断する。その意味でもマクロ社会学からの現状分析派である 私にとって，高田保馬作品は応用理論の宝庫としても位置づけられる。

とりわけ輸入紹介業と表裏一体の「創造的学説衰亡の法則」(盛山和夫「高田社 会学に挹ける勢力理論」金子勇編『高田保馬リカバリー』ミネルヴァ書房，2003） を克服するためにも，高田保馬の社会学理論から現代社会に蘇る「学説の創造」 を示してみたいと願った。『高田保馬リカバリー』後半の第部「継承と応用」の 4本の展望論文と復刻版の巻末解説論文はその試みである. 碩学の胸を借りて, 現 状分析の理論や深化した学説を後発の研究者がそれぞれ独自に開陳したのに，早 
川が「評者の手に負えるものではない」として一顧だにしなかったことはまこと に残念である。これら書き下ろし論文こそが「リカバリー」の成否を占うのであ り,「継承と応用」のレベル次第で，早川がいう「つまらなさ」の理由も鮮明にな るはずであうた。

$\lceil 4$ 冊本」の姿が見えた 2003 年 11 月に, 私は高田社会学全体を念頭においた 「テーマセッション」を中央大学での日本社会学会第 76 回大会で「高田保馬リカ バリー」として実施した，抒そらく 31 年ぶりの学会大会での高田関連の集合的議 論であったはずであり，そこからは今後の「リカバリー」の方向性も浮かんでき た.

読みにくさを理由に読まない人が増えないように，旧漢字・旧かなづかいを現 代表記に極力变えて, 索引を付加し, 詳しい解説論文を用意したのは, 先行学説 への態度を私なりに実践したかったからである。これは形式面での配慮であるが， 内容としての学説継承態度についても触れておこう。

早川はジンメル研究者である立場から，『高田保馬リカバリー』と『階級及第三 史観』で私が高田保馬「人口史観」＝「第三史観」に触れた際の「誤解」を指摘 している。ジンメル理論だけから高田保馬が「第三史観」を創造したわけではな いことは承知している．なによりも本人が旧版『階級及第三史観』(関書院，1948） でも新版でもそのv頁で「マルサス人口法則+デュルケム+テンニイス＝第三史 観」という公式を明記している。そこには確かにジンメルの名前はない。しかし 同時に，旧版223頁（新版 197頁）にジンメルのいくつかの言説を手がかりに，唯 心史観と唯物史観の精緻な検討を踏まえて練り上げたことが記してある。そこで 「経済も社会学的変化によって規定され, 経済形態も『上部構造』にすぎない」 （清水幾太郎訳『社会学の根本問題』1979：30-31）といったジンメルの該当個所 をわざわざ紹介したのである。これは私なりの学説研究の姿勢である.

また早川の「書評論文」では，「学説のパッチワーク」が批判の根拠として2回 も用いられている。しかし「学説のパッチワーク」はメドレーでもあり，そこに 強力な磁石となる柱があれば, 社会学的想像力を媒介として社会学的創造力を強 化させる可能性をむしろ秘めているのではないか，異なるデー夕を結びつけ，違 つた観点を組み合わせるところから，社会学的創造力は誕生する（金子『社会学 的創造力』ミネルヴァ書房，2000)。「4冊本」にみられる「学説のパッチワーク」 はその証明とも読める。

『高田保馬リカバリー』企画と並行して「パーソンズ・ルネッサンス」企画が同 時進行していた（富永健一・徳安彰編『パーソンズ・ルネッサンスへの招待』勁 草書房，2004）。「ルネッサンス」ではなく私は「リカバリー」を標榜したが，早 川が言うような「病気（イルネス）」からの回復とは見なさず，大内兵衛や向坂逸 郎らマルクス経済学者とその系統の社会学者に賠められた評価を見直し，高田理 論社会学がもつ現実的有効性を「正当に評価」することが隠された意図であった．

周知のように，福武直とそのグループが高田保馬も鈴木栄太郎もマルクス主義 
の立場から一貫して論難した．私は高田理論社会学と「引用すべき個所が，部分 ではなく全体にある」(鈴木栄太郎『日本農村社会学原理 上』未來社，1968：136) として高田「全体社会論」の全面摂取をした鈴木実証社会学の成果を高く評価す る.

東京在住のマルクス主義者を〈東マ〉とすれば，高田保馬・鈴木栄太郎路線は 〈非東マ〉になる。〈非東マ〉を集団的に貶めていた〈東マ〉は，20年前まで国家 独占資本主義論を唱え, 「地域の不均等発展」を日本資本主義の特質と断定しつつ も，20倍以上の地域の不均等格差がある中華人民共和国の現状にはまったく沈黙 したままである。それは「社会学の後進国であった」時代のことではなく，今も 変わらない. 異質の現状に直面して議論しないこの沈黙は学界の「軽薄さ」では なく，本質的な病理であり，そのまま〈非東マ〉も含んだ社会学全体への社会的 評価の低下に結びつく.

$\lceil 4$ 冊本」を刊行したあと, 高田保馬の遺族と高弟の方々に挨拶に出向いた際に, 高田保馬がなぜ文化勲章ではなく, 文化功労者であったかという興味深いエピソ 一ドを聞いた。そのいきさつもやはり学界の病理としかいいようがないが，病理 を超える見識を「4 冊本」が教えてくれる。「高田先生は，包括的全体社会に焦点 を抄き，その理論的考察に専心され，見事な体系的展開を残された」（青山秀夫 「若い人々のための高田保馬先生」『高田保馬博士の生涯と学説』前揭: 170). こ の継承を〈非東マ〉の「4冊本」精読から開始してほしいと願う. 